\title{
MTHFR wt Allele
}

National Cancer Institute

\section{Source}

National Cancer Institute. MTHFR wt Allele. NCI Thesaurus. Code C50893.

Human MTHFR wild-type allele is located in the vicinity of 1 p36.3 and is approximately 19 $\mathrm{kb}$ in length. This allele, which encodes methylenetetrahydrofolate reductase protein, plays a role in the methylation of homocysteine to form methionine. Allelic variants of the MTHFR gene are associated with susceptibility to numerous disorders including acute leukemia, colon cancer, neural tube defects and occlusive vascular disease. 